Administrative Issues Journal: Connecting Education, Practice, and Research, Summer 2016, Vol. 6, No. 1: 118-133. DOI: 10.5929/2016.6.1.8

\title{
If You Are Like Me, I Think You Are More Authentic: An Analysis of the Interaction of Follower and Leader Gender
}

\author{
Sandra Tibbs, Ph.D. \\ Neverest Solutions, Vienna, VA, \& Our Lady of the Lake University, San Antonio, TX \\ Mark T. Green, Ph.D. \\ Esther Gergen, Ph.D. \\ Jared A. Montoya, Ph.D. \\ Our Lady of the Lake University, San Antonio, TX
}

\begin{abstract}
Within the empirical literature related to leadership, female leaders are regularly rated higher on dimensions such as being transformational and being effective. Some studies have found that gender plays a role in the follower-leader relationship, and this interaction can be assessed. An emerging model of leadership is authentic leadership. This article analyzed whether there was an interaction between the gender of the leader and gender of the follower when assessing how authentic leaders were. Female followers rated female leaders higher on authenticity than male leaders, while male followers rated male leaders as more authentic than female leaders. Implications for the practice of leadership are discussed.
\end{abstract}

Keywords: authentic leadership, leader gender, follower gender

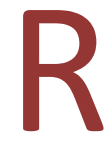

esearch on ways in which male and female leaders differ has been ongoing for decades. In a seminal meta-analytic study, Eagly (2003), for example, found that female leaders were rated more transformational than male leaders. Male leaders, on the other hand, were rated higher on the transactional behaviors of management-by-exception active, and the passive avoidant behaviors of management by exception passive and laissez-faire.

An important moderator variable analyzed in several gender and leadership studies has been the gender of the follower. Paustian-Underdahl, Walker and Woehr (2014), for example, meta-analyzed 99 effect sizes for leader effectiveness. When all leadership contexts were considered, men and women did not differ in perceived leadership effectiveness. However, when the leaders were rated by a majority of female followers, female leaders were rated more effective than male leaders. The difference became 
smaller in gender-balanced groups. For groups in which the majority of followers were male, there were no differences in ratings of leader effectiveness as a result of the leaders' gender.

In another study, Elsesser and Lever (2011) analyzed responses from 60,470 women and men who participated in a survey on the MSNBC web site. Among the findings were that men judged their female bosses slightly more favorably than their male bosses, and women judged their male bosses slightly more favorably than their female bosses.

\section{Purpose of the Study}

The Eagly (2003) meta-analysis was performed on studies using the construct of transformational leadership. Paustian-Underdahl, Walker and Woehr's (2014) meta-analysis found cross-gender differences in ratings of leadership effectiveness, but did not analyze leadership style. The large-scale study by Elsesser and Lever (2011) found cross-gender differences in the leadership constructs of leader competence, leader directness, and leader sensitivity.

As new theories and models of leadership emerge, it is important to assess whether they are influenced by the gender of the follower. An emerging model of leadership, which has gained increased interest, is authentic leadership (Walumbwa, Avolio, Gardner, Wernsing, \& Peterson, 2008). This model emphasizes transparency, morality, being balanced in soliciting ideas and working on self-awareness. An area that has yet to be sufficiently explored is whether differences in the ratings of leaders' authentic leadership are influenced by the gender of the follower.

\section{Previous Research}

\section{Authentic Leadership}

Authenticity is not a new concept; it can be traced back to the ancient Greek philosophy, "Know Thyself," which was inscribed in the Temple of Apollo at Delphi (Parke \& Wormell, 1956). Authenticity has been shown to influence individual well-being and enduring social relationships (Erickson, 1995; Rogers, 1959). Maslow (1968) suggested that satisfying higher order needs was a precondition to authenticity.

The authentic leadership construct encompasses four dimensions. Self-awareness is a dynamic process and is the degree to which the leader reflects and demonstrates an understanding of how (s)he derives and makes sense of the world and is aware of his or her strengths, limitations, how others see him or her, and how (s)he impacts others (Kernis, 2003; Walumbwa et al., 2008). Balanced processing is the degree to which the leader shows that (s)he objectively analyzes the relevant data and solicits others' views that challenge his or her deeply held beliefs, before making a decision (Gardner, Avolio, Luthans, May, \& Walumbwa, 2005; Walumbwa et al., 2008). Internalized moral perspective refers to the degree to which the leader sets a high standard for moral and ethical conduct, and lets those standards consistently guide his or her decisions and actions versus external pressures such as group, organizational, and societal pressures (Avolio \& Gardner, 2005; Gardner et al., 2005; Walumbwa et al., 
2008). Relational transparency is the degree to which the leader presents his/her true self (as opposed to a false and distorted self) to others, openly shares information, and expresses his/her true thoughts and feelings, reinforcing a level of openness with others that allows others to be comfortable and forthcoming with their ideas, challenges, and opinions (Avolio et al., 2005; Gardner et al., 2005; Walumbwa et al., 2008).

With the incorporation of a moral and ethical perspective, the theory of authentic leadership moves beyond transformational or full-range leadership (Avolio et al., 2005) to serve as a foundation for understanding leadership, independent of style (George, 2003; Hughes, 2005; Luthans \& Avolio, 2003). Avolio et al. (2005) argued that authentic leadership can be viewed as a "root construct" for other leadership processes.

To date, multiple studies have found a significant positive correlation between authentic leadership and ethical leadership and behavior, as well as moral courage and employee trust in their leaders (Bird, Wang, Watson, \& Murray, 2009; Clapp-Smith, Vogelgesang, \& Avey, 2009; Hannah, Avolio, \& Walumbwa, 2011; Hassan \& Ahmed, 2011; Hsiung, 2012; Leroy, Palanski, \& Simons, 2012; Walumbwa et al., 2008; Wang \& Bird, 2011; Wang \& Hsiech, 2013; Wong \& Giallonardo, 2013; Wong, Laschinger, \& Cummings, 2010; Zamahani, Ghorbani, \& Rezaei, 2011). In support of Avolio and Gardner's argument, multiple studies have also found a significant positive correlation with others aspects of leadership such as transformational leadership, identification with supervisor, leader consistency, leader predictability, leader competence, leader benevolence, leader reliability, and leader-member exchange (Clapp-Smith, Vogelgesang, \& Avey, 2009; Green, 2015; Hsiung, 2012; Peus, Wesche, Streicher, Braun, \& Frey, 2012; Tokin, 2013; Walumbwa, et al., 2008; Walumbwa, Wang, Wang, Schaubroeck, \& Avolio, 2010; Wang \& Bird, 2011).

Empirical evidence supports the idea that authentic leadership influences employees' work attitudes. Multiple studies have found a positive correlation between job satisfaction and empowerment (Giallonardo, Wong, \& Iwasiw, 2010; Tonkin, 2013; Walumbwa, et al., 2008; Walumbwa, et al., 2010; Wang \& Bird, 2011; Wong \& Laschinger, 2013). Other studies have found empirical evidence to support a positive correlation between authentic leadership and followers' organizational citizenship behavior and climate (Valsania, Moriano, Moleor, \& Topa, 2012; Walumbwa et al., 2008; Walumbwa et al., 2010; Woolley et al., 2011). In addition, multiple studies have found a significant correlation between authentic leadership and job performance (Clapp-Smith, 2009; Leroy et al., 2012; Walumbwa et al., 2008; Walumbwa et al., 2011; Zamahani et al., 2011).

Authentic leadership at the group level has also been found to have a positive correlation with outcomes for teams in the areas of effectiveness, virtuousness, commitment, and potency (Hmieleski, Cole, \& Baron, 2012; Peu et al., 2012; Rego, Vitoria, Magalaes, Ribeiro, \& Cunha, 2013). Authentic leadership has been found to be positively correlated with employee commitment (Leroy et al., 2012; Peus et al., 2012; Rego et al., 2013) and work engagement (Bird et al., 2009; Giallonardo et al., 2010; Hassan et al., 2011; Walumbwa et al., 2010; Wang \& Bird, 2011; Wang \& Hsieh, 2013; Wong et al., 2010). Lastly, empirical evidence supports that authentic leadership influences employees' psychological 
capital (Rego, Sousa, Marques, \& Cunha, 2012; Walumbwa, Luthans, Avey, \& Oke, 2011; Woolley, Caza, \& Levy, 2011).

\section{Cross-Gender Leadership Studies}

Meta-analyses. Several previous studies have analyzed how the gender of the follower influences the ratings of leadership given to leaders. Kis and Konan (2014) conducted a meta-analysis of 38 studies with a total sample of 15,280 teachers and found that male teachers rated their principals' instructional behaviors higher than female teachers $(\mathrm{d}=.04)$. Paustina-Underdahl, Slattery, and Woeht (2014) conducted a meta-analysis for leader effectiveness. The analysis didn't address the gender of the follower, but did find that the source of the ratings for male and female leaders influenced the ratings given to male or female leaders. Overall, female leaders were rated slightly higher than male leaders $(k=$ $99, N=101,676, d=-.05)$. Variations in ratings, however, existed for who rates whom. When rated by subordinates $(k=32, N=63,450,676, d=-.08)$ or bosses $(k=9, N=13,273, d=-.16)$ female leaders were rated as more effective. When leaders rated themselves, male leaders believed they were more effective than female leaders $(k=19, N=4711, d=.18$ ).

Additional studies. Afolabi (2013) found that stereotypes against women leaders in Nigeria had a significant negative effect on women leaders' job performance and perceived level of achievement. They also found that female subordinates rated their female leaders higher on level of achievement than their male counterparts. Follower gender, however, had no effect on the way female leaders were rated by their subordinates on job performance. Ayman, Korabik, and Morris (2009) found that the relationship between a leader's self-report on transformational leadership and their subordinates' evaluation of their performance was significantly less positive for female leaders with male subordinates than for female leaders with female subordinates. For male leaders, their male and female subordinates rated their performance as equally effective, regardless of their levels of transformational leadership. Van Emmerik, Wendt, and Euwema (2010) analyzed data from 12,546 managers in 437 organizations in 32 countries. After controlling for societal influences, a higher gender ratio (relatively more female managers) was positively associated with consideration and negatively related to initiating structure. Male managers in organizations with more female managers tended to engage less in initiating structure, whereas the leadership behaviors of female managers were not associated with the gender ratio.

\section{The Authentic Leadership Questionnaire}

The Authentic Leadership Questionnaire consists of 4 subscales: self-awareness (4 items), relational transparency ( 5 items), internalized moral perspective ( 4 items), and balanced processing ( 3 items). The four dimensions form a higher-order authentic leadership factor (Walumbwa, et al., 2007). Walumbwa, et al. (2007) reported the internal reliability (Cronbach's alpha) for each ALQ measure was as follows: self-awareness, .73; rational transparency, .77; internalized moral perspective, .73; and balanced processing, .70. 
In this study the authentic leadership dimensions had the following reliability (Cronbach's alpha): selfawareness, .93; rational transparency, .88; internalized moral perspective, .93; and balanced processing, .87 and overall authentic score .97. For the analysis in this study, only the overall authentic score was used.

\section{Participants}

One hundred and ninety-three adults participated in this research. Table 1 provides the composition of the leader and follower gender possibilities.

Table 1

Distribution of Followers and Leader by Gender

\begin{tabular}{lccc}
\hline & Male Follower & Female Follower & Total \\
\hline Male Leader & 55 & 57 & 112 \\
Female Leader & 9 & 72 & 81 \\
Total & 64 & 129 & 193 \\
\hline
\end{tabular}

Participant age in this study ranged from 18 to 70 years old, with a mean age of 45 years. Most participants in this study were born in the U.S. $(N=168)$. Participants who were not born in the U.S. (28) were born in Russia $(N=1)$, Israel $(N=1)$, Mexico $(N=5)$, U.K. $(N=1)$, Peru $(N=6)$, Canada $(N=5)$, Chile $(N=1)$, Germany $(N=4)$, Romania $(N=1)$, Japan $(N=1)$, Guatemala $(N=1)$ and Australia $(N=1)$. The majority of participants in this study were US citizens $(N=181)$. Non-U.S. citizens $(N=14)$ included Israel $(N=2)$, Mexico $(N=2)$, U.K. $(N=1)$, Peru $(N=3)$, Canada $(N=5)$ and Australia $(N=1)$.

The majority of participants in this study indicated they were in a leadership position $(N=108)$. Eightyeight participants indicated they were not in a leadership position. Of those participants who indicated they were currently in a leadership position, they indicated the following leadership positions: President/CEO $(N=2)$, Vice President $(N=18)$, Director $(N=18)$, owner $(N=1)$, Manager/Supervisor $(N$ $=61)$ and other $(N=19)$.

Overall, the sample was quite educated. Twelve participants held a high school degree, 24 had completed some college, 17 held an associate's degree, 52 held a college degree, and 88 held a graduate degree.

One hundred and five participants indicated that their ethnicity was white, 13 were African American, 57 were Hispanic and 18 were coded as other ethnicity besides white, African American, and Hispanic.

\section{Results}

The results of a five-way Analysis of Covariance are shown in Table 2. The main effects of leader gender and follower education were significant. The interaction of follower gender (FG) and leader gender (LG) was also significant. 
Table 2

Five-Way Analysis of Covariance for Authentic Leadership

\begin{tabular}{lcccc}
\hline Source & $\begin{array}{c}\text { Type III Sum of } \\
\text { Squares }\end{array}$ & df & F & Sig. \\
\hline Follower Age & 1.50 & 1 & 2.19 & 0.14 \\
Follower Gender (FG) & 0.53 & 1 & 0.78 & 0.38 \\
Leader Gender (LG) & 2.86 & 1 & 4.16 & 0.04 \\
Follower Ethnicity & 2.76 & 3 & 1.31 & 0.27 \\
Follower Education (Ed) & 12.15 & 2 & 8.86 & 0.00 \\
FG * LG & 4.22 & 1 & 6.15 & 0.01 \\
FG * Ethnicity & 0.39 & 1 & 0.56 & 0.45 \\
FG * Ed & 2.00 & 2 & 1.45 & 0.24 \\
LG * Ethnicity & 0.51 & 1 & 0.75 & 0.39 \\
LG * Ed & 0.20 & 2 & 0.15 & 0.86 \\
Ethnicity * Ed & 1.92 & 3 & 0.93 & 0.43 \\
\hline
\end{tabular}

A one-way analysis of variance (ANOVA) with Scheffe post-hoc analysis found that ratings given to male leaders by male followers $(M=2.75$ ) were not different from ratings given to male leaders by female followers $(M=2.84)$. Ratings male followers gave female leaders $(M=2.37)$, however, were much lower than ratings that female followers gave female leaders $(M=3.09), p=.01$ (see Figure 1).

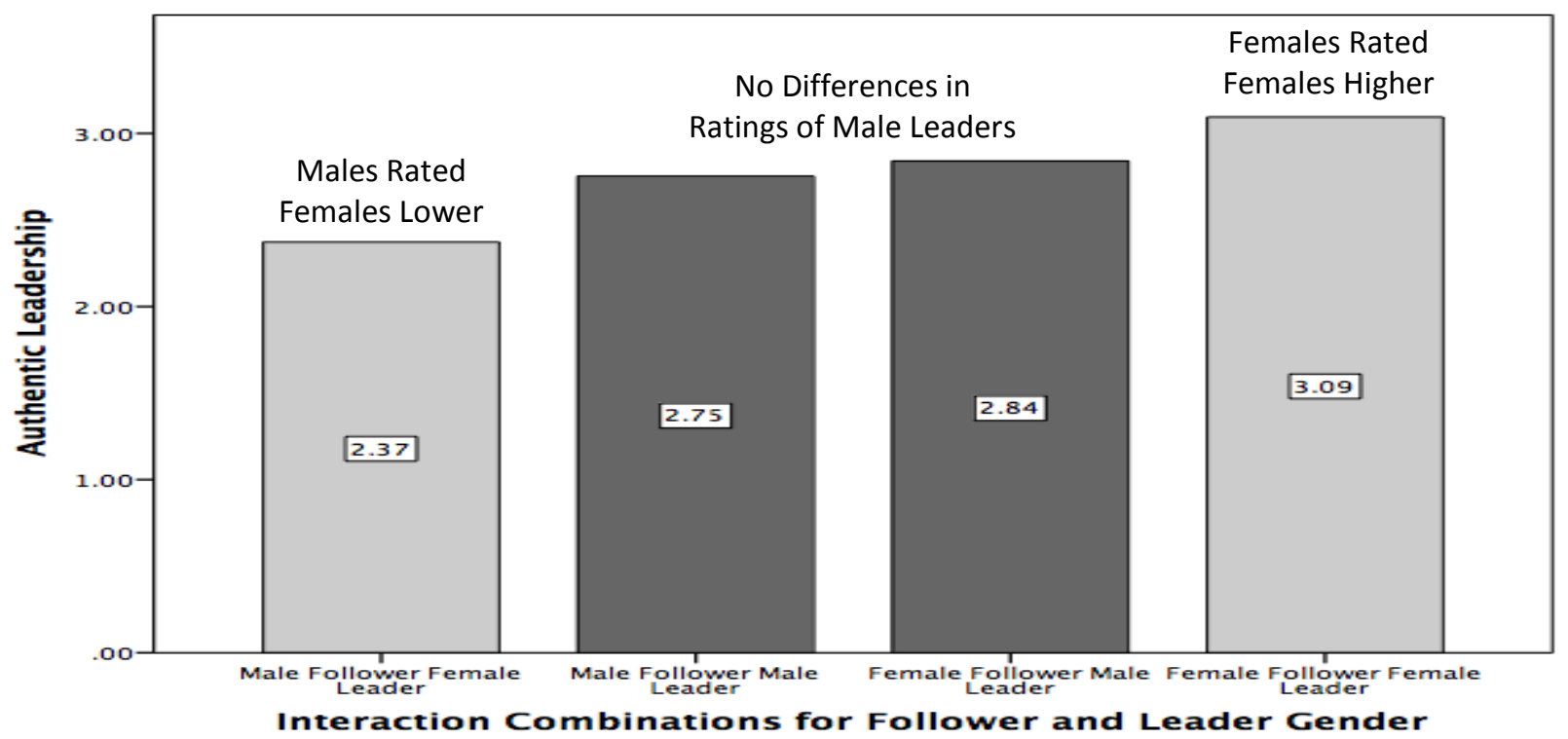

Figure 1. Scheffe post-hoc for the combination of leader gender and follower gender. 
There were also significant differences for leader gender $F(1,192)=4.16, p=.04$. Male leaders $(M=$ 2.86) were rated slightly higher in authentic leadership than female leaders $(M=2.75)$. The interaction of the gender of the follower and the gender of the leader was also significant $F(1,191)=6.15, p=.01$. To further explore the interaction, two additional analyses were conducted. In the first analysis, a composite variable consisting of four groups was created: Male followers rated male leaders, male followers rated female leaders, female followers rated male leaders and female followers rated female leaders.

Based on the initial analysis, understanding the interaction plot in Figure 2 is easier. Generally, female followers rated their leaders as more authentic than male followers. But, of those two combinations, female followers rated female leaders as more authentic than male leaders. Conversely, male followers rated male leaders as more authentic than female leaders.

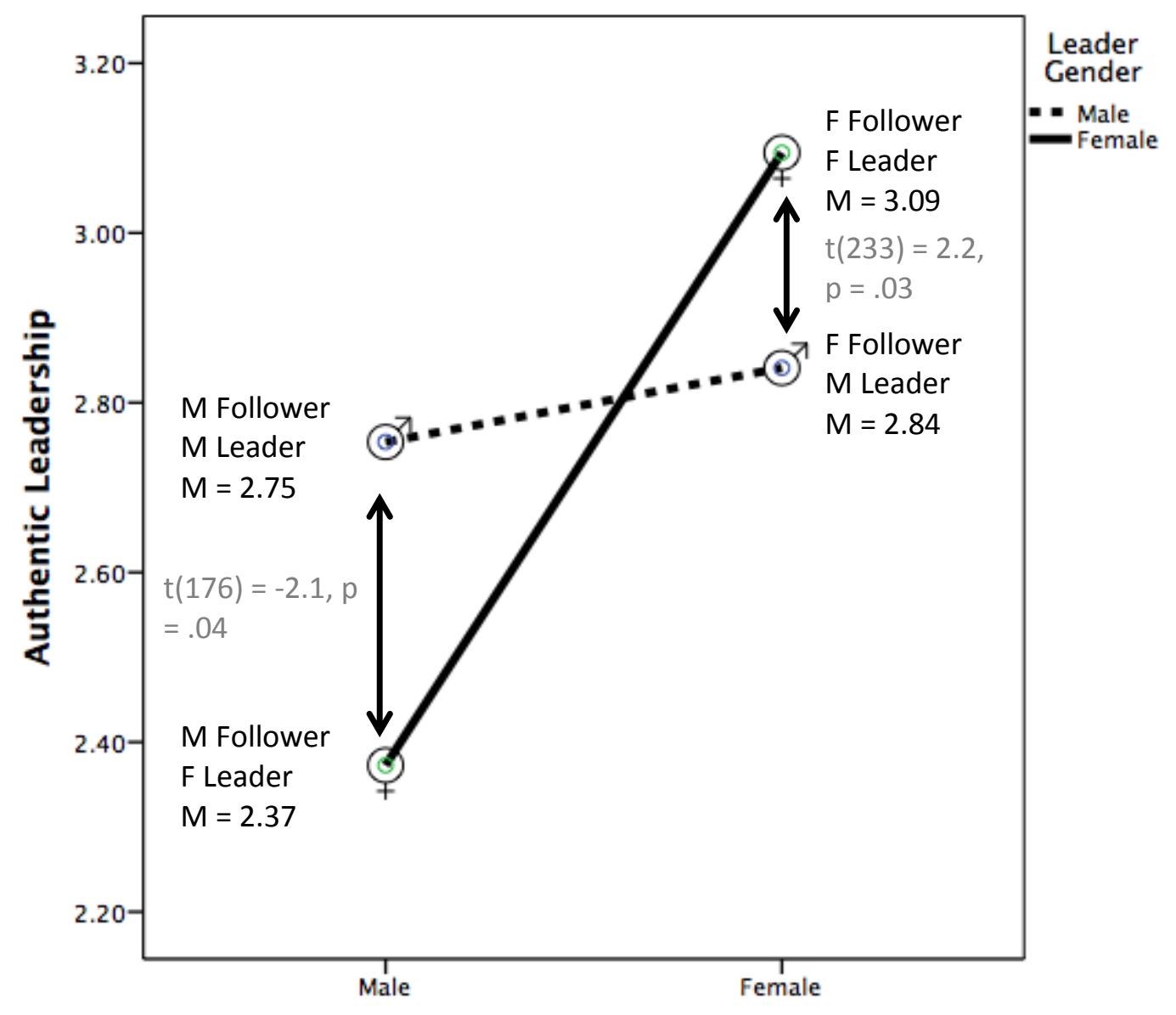

Follower Gender

Figure 2. Interaction plot for the combination of leader gender and follower gender. 


\section{Discussion}

Meta-analytic literature as summarized in Table 3 tends to indicate that there are distinctions in the interpersonal and affective behaviors of females in comparison to males. It is important to remember that these are group differences and do not apply to all females and all males. Rather, the meta-analyses capture the important nuances of differences "overall" between males and females.

Females, for example rate higher on loyalty and genuineness of friends, friendship expectations, forgiveness, and affective speech than males. Conversely, males rate higher on expectations of wealth, status, and risk taking than females.

Facets of authentic leadership such as internalized moral perspective and relational transparency include individual behaviors that connote decision making guided by ethical conduct and openness of self to others. Identifying these authentic behaviors may require a personal understanding and/or familiarity with them via shared interpersonal and affective tendencies. This may explain why this research found that female followers rated female leaders higher on authentic leadership than their male counterparts.

Male followers, in turn, rated male leaders as more authentic than female leaders. Perhaps males' higher ratings on talkativeness foster more relational transparency and balanced processing between male leaders and followers in their interactions, thus leading males to perceive their male leaders as more authentic. Additionally, higher ratings on justice orientation in moral reasoning among males may lead them to become attuned to this aspect in their male leaders' use of internalized moral perspective. Table 4 captures some of these possible reasons that male and female followers might observe leader behaviors differently. 
Table 3

Relevant Meta-Analytic Literature

\begin{tabular}{|c|c|c|c|c|}
\hline Variable & Higher Group & k & $\mathrm{N}$ & $\begin{array}{c}\text { Effect } \\
\text { Size }\end{array}$ \\
\hline \multicolumn{5}{|c|}{ Facial Awareness } \\
\hline Remembering Faces $^{(\mathrm{d})}$ & Females & 20 & & .36 \\
\hline $\begin{array}{l}\text { Understanding Emotions from } \\
\text { Pictures of Eyes Test }{ }^{(k)}\end{array}$ & Females & 42 & & .18 \\
\hline \multicolumn{5}{|c|}{ Friendship Expectations } \\
\hline Overall Friendship Expectations ${ }^{(i)}$ & Females & 36 & 8,825 & .17 \\
\hline Loyalty and Genuineness of Friends ${ }^{(i)}$ & Females & 21 & 5,499 & .17 \\
\hline Self Disclosure and Intimacy of Friends ${ }^{(\mathrm{i})}$ & Females & 31 & 8,245 & .39 \\
\hline Sharing Mutual Activities, Companionship ${ }^{(i)}$ & Females & 21 & 5,118 & .03 \\
\hline Wealth, Status, Physical Attractiveness ${ }^{(i)}$ & Males & 9 & 3,470 & -.34 \\
\hline \multicolumn{5}{|c|}{ Ethical Views } \\
\hline $\begin{array}{l}\text { Care Orientation in Moral Reasoning } \\
\text { Justice Orientation in Moral Reasoning }^{(b)}\end{array}$ & $\begin{array}{l}\text { Females } \\
\text { Males }\end{array}$ & $\begin{array}{c}160 \\
95\end{array}$ & & $\begin{array}{l}-.28 \\
.19\end{array}$ \\
\hline Moral Sensitivity (e) & Females & 19 & 4,000 & .25 \\
\hline \multicolumn{5}{|c|}{ Emotions } \\
\hline Overall Emotional Intelligence ${ }^{(j)}$ & Females & 47 & 16,383 & .07 \\
\hline Forgiveness ${ }^{(a)}$ & Females & 70 & 15,731 & .28 \\
\hline Guilt (h) & Females & 307 & & -.27 \\
\hline Shame ${ }^{(h)}$ & Females & 232 & & -.29 \\
\hline Hubristic Pride ${ }^{(h)}$ & Males & 17 & & .14 \\
\hline \multicolumn{5}{|c|}{ Personality } \\
\hline Risk Taking $^{(f)}$ & Males & 322 & & .13 \\
\hline \multicolumn{5}{|c|}{ Communication } \\
\hline $\begin{array}{l}\text { Smiling }{ }^{(i)} \\
\text { Talkativeness }^{(c)} \\
\text { Affiliative Speech }^{\text {(c) }} \\
\text { Assertive Speech } \\
\text { (c) }\end{array}$ & $\begin{array}{l}\text { Females } \\
\text { Males }\end{array}$ & 418 & 109,654 & .41 \\
\hline \multicolumn{5}{|c|}{ Decision Making } \\
\hline $\begin{array}{l}\text { Rumination }(\mathrm{g}) \\
\text { Brooding }(\mathrm{g})\end{array}$ & $\begin{array}{l}\text { Females } \\
\text { Females }\end{array}$ & $\begin{array}{l}59 \\
23\end{array}$ & $\begin{array}{c}14,321 \\
4,873\end{array}$ & $\begin{array}{l}.24 \\
.19\end{array}$ \\
\hline Reflecting ${ }^{(\mathrm{g})}$ & Females & 21 & $>4,000$ & .17 \\
\hline
\end{tabular}

Note. $k$ is the number of effect sizes analyzed in the meta-analysis. $N$ is the total sample represented by the studies analyzed. The effect size is generally the Cohen $d$ score, but additional details are provided for each study. Studies without the combined sample size $(N)$ shown did not report the combined sample size. (a) Miller, Worthington and McDaniel (2008), the statistic reported is the d; (b) Jaffee and Hyde (2000), the statistic reported is the d; (c) Leaper and Ayres (2007) the statistic reported is the Cohen d score. d) Herlitz and Love (2013) the statistic reported is the weighted Hedges g; (e) You, Maeda and Bebeau, (2011), the statistic reported is the d; (f) Byrnes, Miller and Schafer (1999), the statistic reported is the d. (g) Johnson and Whisman (2013), the statistic reported is the Cohen's d; (h) Else-Quest, Higgins and Morton (2012), the statistic reported is the Weighted Mean Effect Size d; (i) LaFrance, Hecht and Paluck (2003), the statistic reported is the mean weighted effect size; (k) Kirkland, Peterson, Baker, Miller and Pulos (2013), the statistic reported is the mean weighted Hedges g; (i) Hall (2011), the statistic reported is the mean weighted d; (j) Joseph and Newman (2010), the statistic reported is the mean weighted $d$. 
Table 4

Related Meta-Analytic Literature and Aspects of Authentic Leadership

\begin{tabular}{|c|c|c|}
\hline $\begin{array}{l}\text { Meta-Analytic } \\
\text { Construct }\end{array}$ & $\begin{array}{l}\text { Authentic Leadership } \\
\text { Similar Construct }\end{array}$ & Comment \\
\hline $\begin{array}{l}\text { Self Disclosure and } \\
\text { Intimacy of Friends }\end{array}$ & $\begin{array}{l}\text { Relational } \\
\text { Transparency }\end{array}$ & $\begin{array}{l}\text { Female followers may interpret increased self- } \\
\text { disclosure from female leaders as authenticity. }\end{array}$ \\
\hline \multicolumn{2}{|c|}{$\begin{array}{l}\text { Too much/little emphasis on } \\
\text { relationship disclosure versus role boundaries }\end{array}$} & $\begin{array}{l}\text { Male followers may interpret the same behavior } \\
\text { from female leaders as blurring of hierarchical } \\
\text { follower/leader roles. }\end{array}$ \\
\hline $\begin{array}{l}\text { Care versus Justice } \\
\text { Orientation in Moral } \\
\text { Reasoning }\end{array}$ & $\begin{array}{l}\text { Internal Moral } \\
\text { Perspective }\end{array}$ & $\begin{array}{l}\text { Female followers may interpret a justice orientation } \\
\text { and following the rules as a lack of a personal } \\
\text { internal moral compass. }\end{array}$ \\
\hline \multicolumn{2}{|c|}{$\begin{array}{l}\text { Too much/little dependency on } \\
\text { caring versus rules as a moral perspective }\end{array}$} & $\begin{array}{l}\text { Male followers may interpret a care orientation as } \\
\text { lacking a clear, consistent moral orientation, } \\
\text { preferring to follow established rules. }\end{array}$ \\
\hline \multirow[t]{2}{*}{ Rumination, Reflecting } & Balanced Processing & $\begin{array}{l}\text { Female followers may interpret reflection and } \\
\text { rumination as engaging in balanced processing in } \\
\text { decision-making. }\end{array}$ \\
\hline & $\begin{array}{l}\text { h/little } \\
\text { is decisiveness }\end{array}$ & $\begin{array}{l}\text { Male followers might interpret reflection and } \\
\text { rumination as indecisiveness. }\end{array}$ \\
\hline \multirow[t]{2}{*}{ Emotional Intelligence } & Self Awareness & $\begin{array}{l}\text { Female followers may interpret higher emotional } \\
\text { intelligence of female leaders as a form of } \\
\text { authenticity. }\end{array}$ \\
\hline & $\begin{array}{l}\text { ch/little } \\
\text { s substance }\end{array}$ & $\begin{array}{l}\text { Male followers might interpret higher emotional } \\
\text { intelligence of female leaders as deliberate } \\
\text { affective behavior rather than authentic } \\
\text { substantive behavior. }\end{array}$ \\
\hline
\end{tabular}

\section{Conclusion}

Research on how male and female leaders differ has been ongoing for decades. Previous studies have found cross-gender differences in leadership styles (Eagly, 2003), leadership effectiveness (PaustianUnderdahl, Walker \& Woehr, 2014) and in the leadership constructs of leader competence, leader directness and leader sensitivity (Elsesser \& Lever, 2011). This study adds to the body of knowledge about how male and female leaders differ by looking at the leadership style of authentic leadership and finding that followers' gender does influence how authentic a leader is perceived to be, depending upon 
the leader's gender. This study found that, for female leaders, it can be more difficult to be perceived as authentic by their male followers compared to male leaders whose perception of authenticity does not seem to be that different between male and female followers. Although there are many implications associated with the findings of this study, three will be highlighted. Table 5 contains the most recent data (2013) from the U.S. Census Bureau for the percentage of females in management occupations. Overall, females hold $38 \%$ of those positions, while males hold $62 \%$.

Table 5

Percentage of Women is Various Management Occupations

\begin{tabular}{lc}
\hline All Management Occupations & $38 \%$ \\
\hline Construction managers & $7 \%$ \\
Architectural and engineering managers & $9 \%$ \\
Farmers, ranchers, and other agricultural managers & $11 \%$ \\
Transportation, storage, and distribution managers & $18 \%$ \\
Funeral service managers & $19 \%$ \\
Industrial production managers & $19 \%$ \\
Chief executives & $24 \%$ \\
Emergency management directors & $27 \%$ \\
Computer and information systems managers & $28 \%$ \\
General and operations managers & $30 \%$ \\
Managers, all other & $32 \%$ \\
Administrative services managers & $34 \%$ \\
Gaming managers & $39 \%$ \\
Marketing and sales managers & $42 \%$ \\
Food service managers & $45 \%$ \\
Purchasing managers & $45 \%$ \\
Natural sciences managers & $49 \%$ \\
Property, real estate, and community association managers & $51 \%$ \\
Lodging managers & $51 \%$ \\
Training and development managers & $51 \%$ \\
Financial managers & $54 \%$ \\
Postmasters and mail superintendents & $56 \%$ \\
Advertising and promotions managers & $59 \%$ \\
Human resources managers & $59 \%$ \\
Education administrators & $62 \%$ \\
Public relations and fundraising managers & $64 \%$ \\
Social and community service managers & $66 \%$ \\
Medical and health services managers & $69 \%$ \\
Compensation and benefits managers & $77 \%$ \\
\hline
\end{tabular}

In order for female leaders to be able to succeed and be more effective in managerial/leadership roles, especially when leading in a male-dominated environment, becoming more aware of how their behaviors may be affecting how authentic they are perceived by male followers is important. 
Previous studies, for example, have shown that leaders authenticity has a positive effect on employees work attitudes (Giallonardo, Wong, \& Iwasiw, 2010; Tonkin, 2013; Walumbwa, et al., 2008; Wang \& Bird, 2011; Walumbwa, et al., 2010; Wong \& Laschinger, 2013), organizational citizenship behavior and climate (Valsania, Moriano, Moleor, \& Topa, 2012; Walumbwa et al., 2008; Walumbwa et al., 2010; Woolley et al., 2011) and job performance (Clapp-Smith, 2009; Leroy et al., 2012; Walumbwa et al., 2008; Walumbwa et al., 2011; Zamahani et al., 2011). Therefore the more authentic leaders are perceived to be by their followers, the more effective the organization becomes which in turn can increase the organization's bottom line.

Additionally, as the workplace continues to find ways in which to effectively lead generation $Y$ employees, authentic leadership can be a strong tool for leaders to succeed at leading generation $Y$ as they put a high emphasis on authenticity of the leader (Twenge \& Campbell, 2008). As proposed by Mhatre and Conger (2011), authentic leadership can be used to bridge the gap between generation $X$ and generation Y. Lastly, it is important to take into account the findings of this study for leadership development. As programs are created to help leaders develop their authenticity, it is important that these programs address the gender differences and provide female leaders with the tools they need to be able to be perceived as authentic by both male and female followers.

\section{References}

Afolabi, O. A. (2013). Stereotypes against women: How do subordinates perceive the job performance and level of achievement of their leaders? Gender \& Behavior, 11(2), 5698-5706.

Avolio, B. J., \& Gardner, W. L. (2005). Authentic leadership development: Getting to the root of positive forms of leadership. Leadership Quarterly, 16, 315-338.

Ayman, R., Korabik, K., \& Morris, S. (2009). Is transformational leadership always perceived as effective? Male subordinates' devaluation of female transformational leaders. Journal of Applied Social Psychology, 39(4), 852-879.

Bird, J. J., Wang, C., Watson, J. R., \& Murray L. (2009). Relationship among principal authentic leadership and teacher trust and engagement levels. Journal of School Leadership, 19, 153-171.

Clapp-Smith, R., Vogelgesang, G., \& Avey, J. (2009). Authentic leadership and positive psychological capital: The mediating role of trust at the group level of analysis. Organizational Studies, 15(3), 227-240.

Eagly, A. H., Johannesen-Schmidt, M. C., \& Van Engen M. L. (2003). Transformational, transactional, and laissez-faire leadership styles: A meta-analysis comparing women and men. Psychological Bulletin, 129(4), 569-591

Elsesser, K., \& Lever, J. (January 01, 2011). Does gender bias against female leaders persist? Quantitative and qualitative data from a large-scale survey. Human Relations, 64(12), 1555-1578.

Erickson, R. J. (1995). The importance of authenticity for self and society. Symbolic Interaction, 18(2), 121-144.

TIBBS, GREEN, GERGEN, \& MONTOYA / DOI: 10.5929/2016.6.1.8

Page 129 
Gardner, W. L., Avolio, B. J., Luthans, F., May, D. R., \& Walumbwa, F. (2005). "Can you see the real me? A self-based model of authentic leader and follower development. Leadership Quarterly, 16, 343372.

George, W. (2003). Authentic leadership: Rediscovering the secrets to creating lasting value. San Francisco: Jossey-Bass.

Giallonardo, L. M., Wong, C. A., \& Iwasiw, C. L. (2010). Authentic leadership of preceptors: Predictor of new graduate nurses' work engagement and job satisfaction. Journal of Nursing Management, 18, 993-1003.

Green, M. (2015) Graduate Leadership (Vol. 2) (3 ${ }^{\text {rd }}$ ed.). North Charleston, SC: Leadership Press.

Hannah, S. T., Avolio, B. J., \& Walumbwa, F. O. (2011). Relationships between authentic leadership, moral courage, and ethical and pro-social behaviors. Business Ethics Quarterly, 21(4), 555-578.

Hsiung, H. H. (May 01, 2012). Authentic Leadership and Employee Voice Behavior: A Multi-Level Psychological Process. Journal of Business Ethics, 107(3), 349-361.

Hughes, L. (2005). Developing transparent relationships through humor in the authentic leader-follower relationship. In W. L., Gardner, B. J. Avolio, \& F. Walumbwa (Eds.), Authentic leadership theory and practice: Origins, effects and development (Vol. 3, pp. 83-106). Oxford, England: Elsevier.

Joseph, D. L., \& Newman, D. A. (2010). Emotional intelligence: An integrative meta-analysis and cascading model. Journal of Applied Psychology, 95(1), 54-78. doi: 10.1037/a0017286.

Kernis, M. H. (2003). Toward a conceptualization of optimal self-esteem. Psychological Inquiry, 14, 1-26.

Kis, A., \& Konan, N. (2014). A meta-analysis of gender differences in terms of teacher views on the instructional leadership behavior of principals. Educational Sciences: Theory \& Practice, 14(6), 2139-2145.

doi: 10.12738/estp.2014.6.2307.

Leroy, H., Palanski, M. E., \& Simons, T. (2012). Authentic leadership and behavioral integrity as drivers of follower commitment and performance. Journal of Business Ethics, 107, 255-264. doi: 10.1007/s10551-011-1036-1.

Luthans, F., \& Avolio, B. J. (2003). Authentic leadership development. In K. S. Cameron, J. E. Dutton \& R. E. Quinn (Eds.), Positive organizational scholarship: Foundations of a new discipline (pp. 241-258). San Francisco, CA: Berrett-Koehler.

Maslow, A. H. (1968). Motivation and personality ( $3^{\text {rd }}$ ed.). New York: Harper \& Row.

Mhatre, K. H., \& Conger, J. A. (2011) Bridging the gap between gen $x$ and gen y: Lessons from authentic leadership. Journal of Leadership Studies, 5(3), 72-76.

Parke, H. W., \& Wormell, D. E. W. (1956). The Delphic oracle. Oxford: Blackwell. 
Paustina-Underdahl, S. C., Slattery, L., \& Woehr, D. (2014). Gender and perceptions of leadership effectiveness: A meta-analysis of contextual moderators. Journal of Applied Psychology, 99(6), 1129-1145.

Peus, C, Wesche, J. S., Streicher, B., Braun, S., \& Frey, D. (2012). Authentic leadership: An empirical test of its antecedents, consequences, and mediating mechanisms. Journal of Business Ethics, 107, 331-348. doi: 10.1007/s10551-011-1042-3.

Rego, A., Vitória, A., Magalhães, A., Neuza, R., \& Cunha, M. (2013). Are authentic leaders associated with more virtuous, committed and potent teams? The Leadership Quarterly, 24, 61-79.

Rogers, C. (1959). A theory of therapy, personality, and interpersonal relationships as developed in the client-centered framework. In S. Koch (Ed.). Psychology: A study of a science: Vol 3. Formulations of the person and the social context (pp. 184-256). New York: McGraw-Hill.

Tonkin, T. H. (2013). Authentic versus transformational leadership: Assessing their effectiveness on organizational citizenship behavior of followers. International Journal of Business and Public Administration, 10(1), 40-61.

Twenge, J. M., \& Campbell, S. M. (2008). Generational difference in psychological traits and their impact on the workplace. Journal of Managerial Psychology, 23(8), 862-877.

U.S. Census Bureau Full-Time, Year-Round Workers and Median Earnings in the Past 12 Months by Sex and Detailed Occupation: 2013, retrieved from https://www.census.gov/people/io/

Valsania, S. E., Moriano, J. A., Molero, F., \& Topa, G. (2012). Authentic leadership and its effect on employee' organizational citizenship behaviors, Psicothema, 24(4): 561-566.

van Emmerik, H., Wendt, H., \& Euwema, M. C. (2010). Gender ratio, societal culture, and male and female leadership. Journal of Occupational \& Organizational Psychology, 83(4), 895-914. Doi: 10.1348/096317909X478548.

Walumbwa F. O., Avolio, B. J., Gardner, W. L., Wernsing, T. S., \& Peterson, S. J. (2008). Authentic leadership development and validation of a theory-based measure. Journal of Management, 34(1), 89-126.

Walumbwa, F. O., Wang, P., Wang, H., Schaubroeck, J., \& Avolio, B. J. (2010). Psychological processes linking authentic leadership to follower behaviors. The Leadership Quarterly, 21, 901-914.

Wang, D., \& Hsieh, C. (2013). The effect of authentic leadership on employee trust and employee engagement. Social Behavior and Personality, 41(4), 613-624.

Wong, C. A., \& Giallonardo, L. M. (2013). Authentic leadership and nurse-assessed adverse patient outcomes. Journal of Nursing Management, 21, 740-752.

Wong, C. A., \& Laschinger, H. S. (2013). Authentic leadership, performance, and job satisfaction: The mediating role of empowerment. Journal of Advanced Nursing, 69(4), 947-959. 
Wong, C. A., Spence, L. H. K., \& Cummings, G. G. (January 01, 2010). Authentic leadership and nurses' voice behaviour and perceptions of care quality. Journal of Nursing Management, 18(8), 889900.

Woolley, L., Caza, A., \& Levy, L. (2011). Authentic leadership and follower development: Psychological capital, positive work climate, and gender. Journal of Leadership \& Organizational Studies, 10(5), $1-11$.

Zamahani, M., Ghorbani, V. \& Rezaei, F. (2011). Impact of authentic leadership and psychological capital on followers' trust and performance. Australian Journal of Basic and Applied Sciences, 5(12), 658-667.

About the Authors

Sandra Tibbs, Ph.D. (sandratibbs@gmail.com) is an accomplished leader, corporate trainer, speaker and executive coach who has worked with leaders in Fortune 500 companies. Sandra holds an M.S. in Organizational Leadership from Our Lady of the Lake University and a Ph.D. in Leadership Studies from Our Lady of the Lake University. Sandra has over 14 years of leadership experience that include leading at different levels of an organization. She has led more than 800 military and civilian employees while holding two leadership positions, and was part of the executive team while serving as an intelligence officer in the United States Air Force (USAF) supporting National Agencies. As an executive coach, Sandra brings those skills to every training session, speaking event and coaching session, helping leaders move past any blocks they might be currently facing. Sandra specializes in helping leaders develop an authentic and strong leadership presence by connecting with their authentic leadership voice, creating a sphere of influence, and building resilience in themselves and their teams. Her impassioned approach to helping organizations and individuals succeed is unparalleled. Audiences and clients describe her as emotionally intelligent and deeply impactful. As a result she was named one of 101 Top Leadership Speakers by NY Times bestseller and Forbes columnist Kevin Kruse.

Mark T. Green, Ph.D., is a Professor of Leadership Studies at Our Lady of the Lake University in San Antonio, TX. Prior to becoming a college professor, he was an Army officer with assignments at Fort Benning, GA, the Pentagon and the Army Medical Department Center and School. Mark currently teaches doctoral classes in leadership and has chaired over 40 doctoral dissertations. He has published research articles in peer-reviewed literature in areas such as spirituality and leadership, language and leadership, and various predictors of successful leadership. Mark holds a B.A. in Psychology from Westminster College; an M.Ed. in Counseling from the University of Missouri, Columbia; an M.S. in Information Systems from the American University in Washington DC; an M.B.A. from Our Lady of the Lake University; an M.A. in Theology from the Oblate School of Theology and a Ph.D. in Educational Administration from the American University.

Esther Gergen, Ph.D., is an Assistant Professor of Leadership Studies in the School of Business and Leadership at Our Lady of the Lake University. Her executive career began with the HEB Grocery Company for which she was a store director. She led several of the San Antonio store locations. Shortly thereafter, she transitioned into the financial services industry by joining Citigroup as a Client Financial 
Analyst. During her time at Citi, she served in a variety of leadership roles including her final assignment as Director of Credit Sales Strategy. Esther is a native Texan, who was born and raised in El Paso, Texas. She holds a Bachelor's degree in Marketing from Texas A\&M University, and an M.B.A. and Ph.D. in Leadership Studies from Our Lady of the Lake University. She is currently serving as the Chair of the Department of Leadership Studies at Our Lady of the Lake University.

Jared A. Montoya, Ph.D., is an Associate Professor of Leadership Studies in the School of Business and Leadership at Our Lady of the Lake University. He began his career working in human resources for Sears Home Central in Provo, UT and later worked as a recruiter for Select Personnel Services in Los Angeles, CA. Prior to pursuing his graduate education, he worked in São Paulo, Brazil as an English teacher to executives from several multinational corporations. Dr. Montoya was born and raised in Colorado and earned a Bachelor's, Master's, and Ph.D. degree from Brigham Young University in Provo, UT where he specialized in Social Psychology. Dr. Montoya's research focuses on gender, culture, multiculturalism and health. He has researched for non-profit organizations, has published in several academic journals and has presented at a number of national conferences. 